\title{
Conflict Management Strategies and Employees' Productivity in a Nigerian State Civil Service
}

\author{
Uwa Kinsley Lazarus* \\ Department of Business Management, Akwa Ibom State University, Obio- Akpa Campus, Akwa Ibom State \\ *Corresponding author: uwakingsley@yahoo.com
}

Received September 12, 2014; Revised November 14; Accepted November 19, 2014

\begin{abstract}
This study examines the role of conflict management strategies on employees' productivity in a Nigerian civil service. Four conflict management strategies were considered which include collective bargaining, negotiation, avoidance and imposing. The descriptive survey design was adopted and self developed questionnaire tagged Conflict Management Strategies and Employees' Productivity Questionnaire was used in the data collection. The reliability of the instrument was tested and Cronbach Alpha reliability coefficient of 0.92 was obtained for the whole instrument. Taro Yamane formula was used in determining sample size and stratified random sampling technique was used in selecting 240 respondents from a cross-section of four ministries in Akwa Ibom State Civil Service, South- South, Nigeria. Pearson Product Moment Correlation and multiple regression were used to analyse the hypotheses. Collective bargaining and negotiation showed a significant positive contribution to employees' productivity while that obtained for avoidance and imposing were significantly negative. Also, collective bargaining and negotiation were significantly positively related to employees' productivity. Therefore, it was recommended that conflict in whatever level should not be ignored but should be effectively managed for better employees' productivity in the workplace. Workers at all level should be trained and given the right behavioural orientation on how to handle conflict. There is also a need for training and retraining of managers on how to effectively managed conflicts for better employees' productivity in the workplace.
\end{abstract}

Keywords: conflict, conflict management strategies, employees productivity

Cite This Article: Uwa Kinsley Lazarus, “Conflict Management Strategies and Employees’ Productivity in a Nigerian State Civil Service.” Journal of Business and Management Sciences, vol. 2, no. 4 (2014): 90-93. doi: 10.12691/jbms-2-4-2.

\section{Introduction}

Organizations be it public or private, small or big exist essentially to achieve certain economic, social or political objectives. These objectives may be in form of profit making, provision of services, production of goods and increase in sales turnover etc. However, these objectives can only be achieved when human resources are employed to utilize other resources such as raw materials, machineries, money and information (George and Jones, 1996). Organizations are made up of different people with different attitude, beliefs, abilities and personality, therefore conflict is inevitable. There is no organization that can effectively carry out its day to day activities without encountering some form of conflict. Therefore, conflict is the commonest, general and wide- spread phenomenon that is synonymous with group activity and interaction. According to Uya (1992), conflict cannot be completely dissociated from human beings and their endeavours, be it group or organization. This means that conflict is a "necessary evil" that one cannot do without.

Conflict refers to a situation in which there are incompatible goals, cognition or emotion within or between individuals or groups that led to opposition (Uya,
1992). This definition recognises three basic types of conflict which are goal conflict which arises when the desired outcomes are incompatible between groups, cognitive and affective conflict. Cognitive conflict arises as a result of incompatibility of ideas, affective conflict on the order hand usually arise when there is an incompatibility in emotions. Conflict can also arise when two or more values, perspective and opinions are contradictory in nature and have not been agreed upon. Conflict has both positive and negative effect on organization that is why there is a need for effective conflict management strategy.

Conflict management refers to attempt to control or regulate conflict through a number of measures. Conflict management strategies refer to the internal mechanisms used by the various authorities in resolving conflict (Adeyemi and Ademilua, 2012). Constructively managed conflict induces a positive performance while poorly managed conflict heats up the environment to bring about 'dislocation of the entire group and polarization, reduced productivity on job performance, psychological and physical injury, emotional distress and inability to sleep, interference with problem activities, escalation of differences into antagonistic position and malice and increased hostility (Akanji, 2005). Through an effective conflict management, a cooperative atmosphere is created 
to promote opportunities and movements are directed towards non-violent, reconciliation or basic clashing interest (Uchendu, Anijaobi and Odigwe, 2013).

\subsection{Statement of the Problem}

Quite visibly, most organizations have devoted a greater part of economic time and effort to settle conflict related issues. This scenario has continued unabated, hence posing a negative challenge to industrial and economic growth of an organisation. Although, scholars have reasoned that conflict cannot be completely ruled out in any organization (Uchede, Anijaobi \& Odigove, 2013) but then, frequent occurrence of organizational conflict could have an adverse effect on the organization in terms of lost of production hour, reduction in profits, unemployment and of course reduction in income level of the organization. Just like any other organization, Akwa Ibom State Service is still confronted with various forms of conflict both interpersonal and conflict task conflicts. The State civil service has also been criticized that they do not live up to expectation of the masses due to their poor productivity. Therefore, it is very important to examine which of the conflict management strategies could endanger increase in employees' productivity in the workplace given the fact that conflict is inevitable. This is because when conflict is not properly managed, there cannot be an increased productivity.

\subsection{Objectives of the Study}

The objective of this study is to examine the contribution of different conflict management strategies on employees' productivity in the workplace. Specifically, the objectives of this study include

1. To examine the contribution of various conflict management strategies (collective bargaining, negotiation, avoidance and imposing) to employees' productivity in the workplace.

2. To examine the relationship between various conflict management strategies (collective bargaining, negotiation, avoidance and imposing) and employees' productivity in the workplace.

\subsubsection{Research Questions}

The following are the research questions

1. What is the contribution of various conflict management strategies (collective bargaining, negotiation, avoidance and imposing) to employees' productivity in the workplace?

2. How do the different conflict management strategies (of collective bargaining, negotiation, avoidance and imposing) relate to employees' productivity in the workplace?

\subsubsection{Research hypothesis}

1. There is no significant contribution of each of the conflict management strategies (collective bargaining, negotiation, avoiding and imposing) to employees' productivity in the workplace.

2. There is no significant relationship between each of the conflict management strategies and employees' productivity in the workplace.

\subsection{Literature Review}

Conflict was viewed as a negative and undesirable aspect of organizational life in the early days of management research and theorizing (Robbin, 1983). Hence, more attention was directed towards its avoidance (Robbins, 1983). But recently, it has been generally accepted that conflict is somewhat inevitable and is not always or necessarily bad for an organization. If properly managed, conflict can lead to the development of ideas, and can also create internal cohesiveness among groups. Therefore, the key for organizational success is to recognize and manage conflict effectively for the good of the organization, rather than to simply avoiding it. Some of the strategies used in managing conflict include forcing, avoidance, structural changes, compromise and smoothing (Ladipo, 1997).

Also, other management strategies such as suppression, smoothing, compromise, third-party intervention, cooperation, democratic process, job rotation as well as confrontation has also been identified. Problem solving, appeal to superior organizational goals, prevention and avoidance, expression of opportunities and resources, use of authority and command, changing the structure of the organization and compromise were also opined to some of the management strategies used by managers in resolving organizational conflict (Ibukun, 1997). Mcshane and Gilnow (2000) as well as Robbin (2001) collectively proffered the various methods of conflict management strategies to include collective bargaining, reconciliation, negotiation and arbitration. Collective bargaining is a situation whereby the representatives of each group come together with a mandate to work out a solution collectively. Reconciliation is an act of procuring good will or inducing friendly feelings. This involves a situation whereby groups who are in conflict and who have failed to reach agreement, can come together once again to attempt to settle their differences. This is usually attempted before the more serious step of a strike by workers or lockout by management is taken. Negotiations is a process in which two or more parties who have common and conflicting interest state and discuss proposals concerning specific term of a possible agreement. It is a deliberate process, conducted by representatives of the groups deciding to reconcile their differences to reach agreement by consensus. Arbitration is one of the conflict management strategies in which an independent person act as an adjudicator or judge in dispute to decide on the terms of settlement. Both parties in the conflict have to agree with who the arbitrator should be, and that the decision of the arbitrator will be binding on them all. The arbitrator listens to and investigates the demands and counterdemands, hence, takeover the role of decision- making.

Conflict is not properly managed could result to strikes and lockout most especially in the Civil service which could have resultant effect on the Psychology of the staff. It can also affect the nation both politically and economically. If conflicts are not properly managed, it can result to bad feelings, low turnover and costly litigation (Hirschman, 2001) but when properly managed, can result to increased individual participation, innovativeness and increased employee's productivity (Uline, Tschannenmoran, \& Perez, 2003). 
Hong, (2005) conducted a study to compare conflict management strategies (CMS) between Koreans and Americans. Six hundred (600) respondents took part in the study involving 300 Koreans and 300 Americans, the study showed that Koreans prefer an avoidance conflict management and a cooperative orientation, whereas the American prefers a competition strategy and an assertive orientation. Also, Lee \& Rogan (1991) examined the conflict management styles of local government employee with superiors, peers and subordinates. The study made used of mail survey and personal interview in data collection. The study found that the conflict management styles used by government employees varied depending on the relative status. Lee \& Rogan (1991) found that in conflict with peers, Korean tend to use the compromising style, most frequently and then followed by integration obliging, dominating and avoidance respectively.

\section{Methodology}

This study adopts the descriptive research design of survey type. Self developed questionnaire was used in data collection. The questionnaire was divided into three main sections. Section A measures the demographic of the respondents; section $B$ assessed each of the four conflict management strategies. The last section, which is section C, measured employees' performance. Section A comprised two items, section B was made of 16 items with four items each used to measure each of the four conflict management strategies considered (collective bargaining, negotiation, imposing and avoidance). Section $\mathrm{C}$ comprised 5 items. All items in section B and C were rated on a four point Likert Scale of strongly agree (SA), agree (A), disagree (D) and strongly disagree (SD). The population of the study comprised employees in the selected four ministries in Akwa Ibom State Civil Service. The determination of sample size was done using the Taro Yamene formula and stratified random sampling technique was used to select 240 employees of Akwa Ibom State Civil Service. These samples were selected from six ministries namely Ministry of Finance, Ministry of Information, Ministry of Health, Ministry of Education, Ministry of Agriculture and Natural Resources and Ministry of Works. The instrument "Conflict Management Strategies and Employees' Productivity Questionnaire” was pretested for reliability and the Cronbach Reliability coefficient of 0.92 was obtained for the whole questionnaire. Multiple regression and Pearson Product Moment Correlation were used to test research hypotheses. Pearson correlation was used to examine whether there is a relationship between the variables. It provides an index of the strength and direction of the relationship between variables. Multiple regression was adopted for studying the relationship between one dependent variable and more than independent variables. It is applied to determine how well a set of variables are able to predict a particular outcome, and which variables are significant predictor of the outcome. (Sekaran, 2003). The Statistical Package for Social Sciences (SPSS version 20.0) was used to facilitate data analysis.

\section{Results}

\subsection{Hypothesis One}

There is no significant contribution of each of the conflict management strategies (collective bargaining, negotiation, avoidance and imposing) to employees' productivity in the workplace.

Table 1. Multiple Regression Analysis of the contribution of various conflict management strategies on employees' productivity

\begin{tabular}{|c|c|c|c|c|c|}
\hline Conflict Management Strategies & $\mathrm{B}$ & S.E & Standardized Beta & $\mathrm{t}$ & p value \\
\hline Collective bargaining & 0.778 & 0.050 & 0.626 & 15.69 & $<0.001^{* *}$ \\
\hline Negotiation & 0.572 & 0.062 & 0.364 & 9.19 & $<0.001^{* *}$ \\
\hline Avoidance & -0.043 & 0.033 & -0.364 & -1.30 & 0.196 \\
\hline Imposing & -0.091 & 0.033 & -0.066 & -2.71 & $0.007 * *$ \\
\hline Constant & -2.612 & 0.538 & -0.000 & -4.86 & $<0.001$ \\
\hline
\end{tabular}

** significant contribution at $0.01(\mathrm{p}<0.01), \mathrm{R}=0.94, \mathrm{R}^{2}=0.88$

Employees' productivity $=-2.612+0.778 *$ collective bargaining $+0.572 *$ negotiation $-0.043 *$ avoidance $-0.091 *$ imposing .

The results presented in Table 1 showed that collective bargaining $(\mathrm{B}=0.778$, $\mathrm{t}$ calc. $=15.69$, $\mathrm{p}<0.001)$ has a significant positive contribution to employees' performance. Negotiation as a conflict management strategies showed a significant contribution to employees' productivity $(\mathrm{B}=0.572, \mathrm{t}$ calc. $=9.19, \mathrm{p}<0.001)$. Avoidance showed an insignificant positive contribution to employee' productivity $\mathrm{B}=-0.043$, $\mathrm{t}$ calc. $=-1.30$, $\mathrm{p}=0.196, \mathrm{p}>0.05)$. For imposing, the results revealed a significant negative contribution to employees' productivity $(\mathrm{B}=-0.091, \mathrm{t}=-2.71, \mathrm{p}=0.007, \mathrm{p}<.001)$. It

therefore means that collective bargaining and negotiation can be term to be an effective means of conflict management strategies that will trigger a better employee's productivity when conflicts are properly managed, it results to an improved productivity. Based on the result of the standardized beta, the conflict resolution strategy that influenced the varaince in employees' productivity the most is collective bargaining.

\subsection{Hypothesis Two}

Table 2. Pearson Product Moment analysis of the relationship between conflict management's styles and employees' productivity in the workplace

\begin{tabular}{|c|c|c|c|c|c|}
\hline Variables & Collective bargaining & Avoidance & Negotiation & Imposing & Productivity \\
\hline Collective bargaining & 1 & & & & \\
\hline Avoidance & $0.197 * *$ & 1 & & & \\
\hline Negotiation & $0.81^{* *}$ & 0.119 & 1 & & \\
\hline Imposing & 0.09 & $0.29 * *$ & $0.13^{*}$ & 1 & \\
\hline Productivity & $0.91 * *$ & 0.12 & $0.86 * *$ & 0.03 & 1 \\
\hline
\end{tabular}

*significantly related at $0.05(\mathrm{p}<0.05),{ }^{* *}$ significantly related at $0.01(\mathrm{p}<0.01)$. 
The results in Table 2 showed a significant positive relationship between collective bargaining and employees' productivity in the workplace $(\mathrm{r}=0.91, \mathrm{p}<0.001)$ and negotiation and employees' productivity( $\mathrm{r}=0.86$, $\mathrm{p}<0.001)$. The results obtained for avoidance and imposing were not significant $(r=0.12, p>0.05$ and $r=0.03$, $\mathrm{p}>0.05$ respectively). This means that when collective bargaining and negotiation are used to manage workplace conflict, it will result to an improvement in performance unlike avoidance and imposing method which does not enhance employees’ productivity.

\section{Discussion of the Findings}

This study has shown a significant positive contribution of collective bargaining and negotiation as conflict management strategies to have a significant contribution to employees' productivity. Finding has also revealed that imposing as a conflict management strategy has a negative significant contribution to employees' productivity. Avoidance showed an insignificantly negative contribution to employees' productivity. This therefore means that collecting bargaining and negotiation are the conflict management strategies that can enhance employees' productivity while imposing and avoidance will discourage employees' productivity. In addition, collective bargaining and negotiation were significantly positively related to employees' productivity while imposing and avoidance are insignificantly related with employees' performance in the workplace. The results of this study have been supported by other similar studies (Meyer, 2004; Rahim and Burtzman, 1989, Vigil-King, 2000). Meyer 204 observed that cooperative conflict management strategies (collective bargaining, negotiation, compromising) tends to yield beneficial outcomes in the workplace unlike the uncooperative conflict management styles like forcing and imposing.

\section{Conclusion}

This study has examined the contribution as well as the relationship between different conflict management strategies and employees' productivity in the workplace. Cooperative conflict management strategies which are collective bargaining and negotiation revealed a significant positive contribution to employees' productivity. A significant positive relationship was also obtained between collective bargaining and employees' productivity as well as between negotiation and employees' productivity. Imposing on the other hand showed a significant negative contribution to employees' productivity, while avoidance was insignificantly related. Therefore, collecting bargaining and negotiation can enhance employees' productivity unlike the use of force.

\section{Recommendations}

Based on the findings of this study, the following are the recommendations
1. Organizations be it private or public, small or big should formulate and execute policies, programmes, rules and actions that are legal and employees based.

2. Conflict in whatever level should not be ignored but should be effectively managed for better employees' productivity in the workplace.

3. Workers at all level should be trained and given the right behavioural orientation as to reduce the occurrence of conflict at workplace.

4. There is a need for training and retraining of managers on how to effectively manage conflict to enhance employees’ productivity.

\section{References}

[1] Adeyemi, T.O., and Ademilua, S. O, 2012, Conflict Management Strategies and Administrative Effectiveness in Nigeria Universities. Journal of Emerging Trends in Educational Research and policy: Scholarlink Research Institute Journal, 3(3), 368-375.

[2] Akaniji, T., 2005, Perspectives on Workplace Conflict Management and New Approaches for the Twenty- First Century. In Albert, I. O. (Ed) Perspectives on Peace and Conflict in Africa Essays in Honour of General (Dr.) Abdusalami A. Abubakar, Ibadan: John Arches Publishers.

[3] George, F and Jones, G., 1996, Understanding and Managing Organizational Behaviour: Reading; Addison - Wesley Publishing Company.

[4] Ibukun, W. O, 1997, Educational Management: Theory and Practice. Bamigboye \& Co.

[5] Ladipo, M., 1997, Crisis Management: The Experience of Nigerian Universities. Paper presented at the Conference of the Association of Nigerian Universities' Professional Administrators, $1-2$.

[6] McNamar, C., 2007, Field Guide to Leadership and Supervision; Basic of Conflict Management. Authenticity Consulting.

[7] Meyer, S., 2004, Organizational response to conflict: Future conflict and work outcomes. Social Work Research, 28: 183-190.

[8] Rahim, M. A., and Buntzman, G. F., 1989, Supervisory power bases, styles of handling conflict with subordinates, and subordinate compliance and satisfaction, Journal of Psychology, 123: $195-210$

[9] Robbins, S, 2001, Organizational Behvaiour: $9^{\text {th }}$ edition Prentice Hall Inc. New York. Robbins, S.P. (1983). Organizational Behavior. Prentice Hall, Englewood Cliffs.

[10] Uchendu, C, C, Anijaobi- Idem, F.N and Odigwe F.N, 2013: Conflict Management and Organizational Performance in Secondary Schools in Cross River State: Research Journal in Organizational Psychology and Educational Studies: Emerging Academy Resources, 2(2), 67-71.

[11] Uya, O., 1992, "Nigeria: The land and the People." Buenos Aires ; Edi Public SA

[12] Vigil-King, D.C, 2000, Team conflict, Integrative ConflictManagement Strategies, and Team Effectiveness; Unpublished Doctoral Dissertation, University of Tennessee, Knoxville

[13] Sekeran, U., 2003, Research method for business: A skill building approach, $4^{\text {th }}$ edition, John Wiley \& Sons.

[14] Hirschman, C.,2001, Order in the haer, HR Magazine, 46(7), 5864.

[15] Lee, H.O, Rogan, R.G., 1991, "A Cross- cultural comparison of organizational Conflict management behaviours", International Journals of Conflict Management, 2(3), 18-99.

[16] Uline, L.C., Tschannen- Moran, M., \& Perez, L.,2003, Constructive conflict: How controversy can contribute to school improvement. Teacher College Recor, 105(5), 782-816.

[17] Hong, J. 2005, Conflict management in an age of globalization: A comparison of intracultural and intercultural conflict management strategies between Koreans and Americans. Global Media Journal, 4(6). 